Testing the Lawyer-induced Litigation Hypothesis in Europe

Peer-reviewed author version

BIELEN, Samantha \& MARNEFFE, Wim (2018) Testing the Lawyer-induced

Litigation Hypothesis in Europe. In: APPLIED ECONOMICS, 50 (16), p. 1837-1851.

DOI: $10.1080 / 00036846.2017 .1374544$

Handle: http://hdl.handle.net/1942/24436 


\title{
Testing the Lawyer-Induced Litigation Hypothesis in Europe
}

\author{
By SAMANTHA BIELEN AND WIM MARNEFFE*
}

Utilizing a European panel dataset, we contribute to the scant empirical literature on the lawyer-induced litigation hypothesis. To address endogeneity problems that arise when estimating the effect of the number of lawyers on civil litigation rates, we use two strategies. We first estimate our model by means of the 2SLS procedure. Second, we exploit the instrumental variable approach based on the linear GMM estimator of Arellano and Bond. The estimations result in a positive and significant effect of lawyers that is robust across the different model specifications and estimation methods in which we address endogeneity. In criminal litigation, where lawyers cannot induce demand, we find no such positive relation between lawyers and litigation.

JEL codes: K41, J44

Keywords: Lawyers, Supplier-Induced Demand, Lawyer-Induced Litigation, Litigation

\footnotetext{
* Hasselt University, Martelarenlaan 42, Hasselt-Belgium (e-mail corresponding author: samantha.bielen@uhasselt.be).

Samantha Bielen would like to thank the Research Foundation Flanders for funding her postdoctoral mandate with grant number $12 \mathrm{~S} 3117 \mathrm{~N}$.
} 


\section{Introduction}

In his seminal work "Institutions, institutional change and economic performance", North (1990) puts forth that court efficiency plays a key role in explaining variation in the differential performance of economies. Given that wellfunctioning judiciaries are a pivotal institutional condition for economic progress (Ramello and Voigt 2012, Posner 1998, North 1990), the functioning of courts has increasingly become the subject of empirical scrutiny among (institutional) economics scholars. This surge is to a great extent motivated by the fact that many judiciaries are faced with an increased litigation rate ${ }^{1}$, which aggravates court delays and hence undermines public confidence in the court system (e.g. Haig and Stone 1993, Johnson 1997, Robel 1992, Westover 1958, Beale 1994, Felli et al. 2008, Geyh 1993, Buscaglia and Dakolias 1999).

Prompted by the development of the first economic analyses of settlement and litigation by Landes (1971), Posner (1973) and Gould (1973), law and economics scholars have persistently researched the causes of litigation (Bielen, Marneffe and Vereeck 2015). “In practice, a lawsuit represents a citizen's choice to invoke the power of the judiciary to settle a dispute rather than to use other means of conflict resolution" (Yates, Davis and Glick 2001, p128). Therefore, changes in the factors that influence the latter decision may cause a proliferation of litigation.

Recently, the discussion on excessive litigiousness has moved to the role of lawyers. More specifically, it is hypothesized that an overabundance of lawyers could incentivize frivolous lawsuits. Strong competition among lawyers can cause them either to lower fees or to persuade clients with low(er) probability cases to file suit. The latter effect, which is called supplier-induced demand, stems from the information asymmetry between legal professionals and their clients, who mainly

\footnotetext{
${ }^{1}$ Scholars regularly refer to a "litigation explosion", "hyperlexis" or "adversary society".
} 
rely on legal advice in their decision to file suit (Cooter and Ulen 2013, Ginsburg and Hoetker 2006, D'Agostino, Sironi and Sobbrio 2012, Zhou 2008, Nelken 2004).

In general, countries have embraced the advantages of fostering competition in the professional service market, particularly in the market for lawyers (Garoupa 2008). Notwithstanding the benefits of competition, excessive competition can induce litigation, which in turn can prompt court backlogs and delays. Given the vital role of lawyers in the strength of the rule of law and the fact that the legal profession is pivotal for institutional quality (Grajzl and Murrell 2005), the hypothesis that lawyers could intentionally induce litigation is worrisome.

Concerns about the growing litigiousness in many European countries and the growing awareness that observed increases in lawyers might further induce litigation rates lead us to the following research question: does a higher lawyer density induce higher civil litigation rates in Europe? To answer this question effectively, we need to address possible endogeneity issues which pose a significant problem for empirical estimation. Furthermore, since the quest for appropriate instruments is challenging, empirical evidence of lawyer induced litigation remains scarce. Although Carmignani and Giacomelli (2010), Buonanno and Galizzi (2014) and Mora-Sanguinetti and Garoupa (2015) find evidence that lawyers induce litigation in Italy and Spain, a cross-country analysis remains non-existent. Our first contribution to the existing literature, therefore, is an analysis of the effect of the number of lawyers on litigation using a panel of countries. For this purpose, we constructed a dataset of 30 countries of the Council of Europe for the years 2006, 2008, 2010, 2012 and 2014. We exploit the panel structure of the dataset to address endogeneity concerns resulting from anticipated unobserved and time-invariant country-level heterogeneity.

Our second contribution to the literature is a methodological one, since we explicitly tackle the problem of reverse causality between lawyers and litigation using several strategies. Following Mora-Sanguinetti and Garoupa (2015), we use 
the number of law schools at a point in time that precedes the timespan of our dataset as an exogenous source of variation for the number of lawyers. Additionally, we propose a new instrument: the number of law graduates (again lagged, to ensure exogeneity), which should be highly correlated with the number of lawyers and uncorrelated with unobserved factors affecting litigation rates. Finally, we tackle the anticipated reverse causality between lawyers and litigation by exploiting the instrumental variable approach based on the linear GMM (General Method of Moments) estimator of Arellano and Bond (1991). GMM estimation has become increasingly popular among researchers because it can improve upon the traditional 2SLS approach. GMM allows for efficient estimation in the presence of heteroscedasticity (Baum, Schaffer and Stillman 2003), avoids the loss of observations when using lags of (internal) instruments (Dimitrova-Grajzl et al. 2016, Roodman 2009) and circumvents the necessity of finding appropriate exogenous instruments. To date, the Arellano-Bond estimator has not yet been used to address the endogeneity concerns between lawyers and litigation rates despite its advantages and popularity in other research areas.

We find that the number of lawyers per 10,000 inhabitants has a positive and statistically significant effect on litigation rates. Ceteris paribus, an increase of the lawyer density with 1 percent, increases litigation rates on average with 1.16 to 1.47 percent. The positive and significant effect of lawyers is robust across the different model specifications and estimation methods in which we address endogeneity.

The paper is structured as follows. Section 2 provides a conceptual framework of the lawyer-induced litigation hypothesis and our empirical model. Section 3 presents the data set and the variables included in the regression models. Section 4 discusses the empirical strategy and presents the results. Section 5 presents some robustness checks and Section 6 concludes with a discussion of the empirical results. 


\section{Conceptual framework and empirical model}

This paper examines the lawyer-induced litigation hypothesis in a European cross-country setting. To this end, we posit the following basic model:

$\log (\text { Litigation })_{\mathrm{it}}=\beta \log (\text { Lawyers })_{\mathrm{it}}+\sum_{c=1}^{C} \log (\text { Controls })_{\mathrm{it}}^{c}+\varepsilon_{\mathrm{it}}$

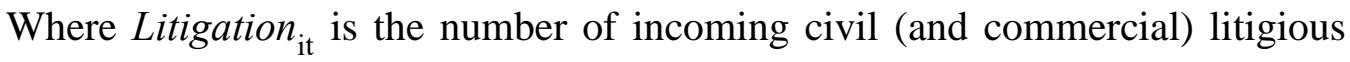
cases at first instance courts as measured in country i in year t. Controls $_{\mathrm{it}}^{\mathrm{c}}(\mathrm{c}=1, \ldots$, 10) is a set of controls that is expected to affect Litigation (i.e. population, population density, number of judges, legal aid, GDP per capita, change in GDP per capita, number of courts, congestion, use of contingency fees, availability of legal insurance) and $\varepsilon_{\text {it }}$ is the error term.

With the model depicted by equation (1), we aim to empirically examine the relationship between the number of lawyers and litigation rates. The existing literature has postulated that a higher lawyer density increases the demand for court services. This stems from the fact that lawyers achieve a target income to which they adjust their work, i.e. the target income hypothesis (Carmignani and Giacomelli 2010). Accordingly, the possible effect of more lawyers and thus more substantial competition among lawyers is twofold. First, the pricing effect predicts that lawyers might feel forced to lower their fees to assure that they have a certain level of work. Second, lawyers might be increasingly pressured to take on cases that previously would not have been brought to court (Cooter and Ulen 2013). In other words, lawyers enduring intense competition could exploit their informational advantage and persuade parties to go to court even when their chance of winning is low. Given that legal advice is a credence good, most parties depend on advice from their lawyer (see e.g. Posner 2014) and the exploitation of informational advantage seems the most plausible explanation for an alleged lawyer-induced litigation 
effect. The pricing effect (that is, litigation is induced because lawyers decrease their fees, and not because they persuade clients to litigate by exploiting their informational advantage) is rather unlikely, at least for those European countries imposing minimum fees for lawyers. ${ }^{2}$

Supplier induced demand is not unique to the lawyer profession. For example in the health care sector, patients do not have the required information and expertise to assess the optimal number of medical services. Following the supplier induced demand hypothesis, physicians take into account private monetary incentives and hence induce medical services. ${ }^{3}$ Studies have found evidence of a supplier induced demand, especially when competition (e.g. amongst doctors or dentists) is tough, for services such as surgeries (Fuchs 1978), dentist services (Birch 1988), laboratory tests (Grytten, Carlsen and Sørensen 1995) and drug prescriptions (Hellerstein 1998). Other applications of the supplier induced demand can be found, for example, in the auto repair market (Peters et al. 2012) and in supplier-buyer contracting (Romano 1994).

Endogeneity concerns complicate the estimation of equation (1). The first source of endogeneity is country-level unobserved heterogeneity: unobservable and omitted country-specific characteristics might have a direct effect on Lawyers and Controls, causing the right-hand side variables to be correlated with the error term. Legal costs, availability of alternative dispute mechanisms, procedural rules and use of technologies (e.g. video conferencing) are likely to affect litigation rates, but cannot be accounted for because of a lack of (consistent) data. The second source of endogeneity is the reverse causality between Lawyers and Litigation. Lawyers are likely to induce the demand for court services but, at the same time, additional

\footnotetext{
${ }^{2}$ For instance, Germany, Slovenia and Italy list minimum fees (European Commission 2004).

${ }^{3}$ Note, however, that the information asymmetry in the healthcare sector is somewhat different compared to the lawyer profession. That is, a patient has little information on the quality of medical care (even after treatment), whereas a litigant at least observes whether he loses the case. Therefore, we expect that if we find evidence of supplier induced demand, the magnitude of the effect will be smaller compared to the effect in the health care sector
} 
litigation will attract more lawyers. Consequently, causation not only runs from the number of lawyers to litigation, but also in the opposite direction and hence Lawyers will be endogenous to Litigation (Carmignani and Giacomelli 2010, Buonanno and Galizzi 2014, Mora-Sanguinetti and Garoupa 2015). Analogously, scholars have had endogeneity issues when analysing the supplier-inducement in the health care sector because health care providers might locate in areas of high demand for their services (Birch 1988).

To avoid erroneous inferences and inaccurate policy recommendations, we address both endogeneity concerns in Section 4. We first proceed with a discussion of our data and variables in Section 3.

\section{Data and variables}

\section{Data}

This paper uses homogeneous data on the daily functioning of the judicial systems of the member states of the European Council. The data was gathered by the Commission for the Efficiency of Justice (hereafter CEPEJ) of the Council of Europe (CEPEJ 2008, 2010, 2012, 2014, 2016). The fact that the data are based on Member States' own responses to an evaluation scheme elaborated by the CEPEJ minimizes difficulties of interpretation of the questions, allowing uniformity despite differences between the organization of judiciaries (CEPEJ 2014). Furthermore, the CEPEJ datasets have the advantage of being collected biennially, allowing international comparisons as well as comparisons over time (Roussey and Deffains 2012). 
For 30 countries $^{4}$ in the period 2006-2014, we observe biennial data on number of new civil (and commercial) cases per 10,000 inhabitants, number of lawyers per 10,000 inhabitants, number of inhabitants, number of inhabitants per square kilometer, number of judges per 10,000 inhabitants, legal aid budget per 10,000 inhabitants, GDP per capita, change in GDP per capita, number of courts per million inhabitants, number of civil (and commercial) pending cases per judge, use of contingency fees and availability of legal insurance. Table 1 provides full description of all variables included in our dataset. Table 2 presents descriptive statistics. Not surprisingly, Table 2 reveals that for each variable (with the exception of Growth), there is more variation across countries than over time.

[Insert Table 1 here]

[Insert Table 2 here]

\section{Dependent variable: measuring litigation}

Following existing literature (see, e.g. D'Agostino, Sironi and Sobbrio 2012, Clemenz and Gugler 2000, Yates, Davis and Glick 2001), we use the litigation rate to measure the demand for court services. More specifically, we use the number of new civil $^{5}$ and commercial legal disputes filed per 10,000 inhabitants in first instance courts in a particular year.

Figure 1 shows the litigation rate for each country in 2014, demonstrating the discrepancies in the propensity to litigate among the countries in our sample (see also the between-variation in Table 2). Scandinavian countries, and more generally

\footnotetext{
${ }^{4}$ Albania, Armenia, Austria, Azerbaijan, Bosnia and Herzegovina, Croatia, Czech Republic, Denmark, Estonia, Finland, France, Germany, Greece, Hungary, Italy, Latvia, Lithuania, Macedonia, Moldova, Montenegro, Norway, Poland, Portugal, Romania, Slovakia, Slovenia, Spain, Sweden, Switzerland and Turkey.

${ }^{5}$ In the CEPEJ questionnaire, "civil law cases" refer to other than criminal law cases and include for example family law cases, commercial law cases, employment dismissal cases and administrative law cases.
} 
countries in Northern Europe, have relatively low litigation rates. Surprisingly, several post-transition countries (such as Croatia and Romania) are among the most litigious countries. Generally, a high propensity to use the court system to resolve civil disputes seems to exist especially in Southern and Eastern Europe countries.

\section{[Insert Figure 1 here]}

The litigation rate varies also considerably from one period to another. Over the past decade, scholars have increasingly reported a rise in civil litigation rates in countries around the world, leading to increasing concerns on the excessive use of courts to resolve disputes (Buscaglia and Dakolias 1999, Clemenz and Gugler 2000, Yates, Davis and Glick 2001, D'Agostino, Sironi and Sobbrio 2012). In our European dataset, litigation rates increased in most countries between 2006 and 2014. The time evolution of litigation rates between 2006 and 2014 is presented in Figure 2.

[Insert Figure 2 here]

Key explanatory variable: measuring the number of lawyers

Our key variable of interest is the number of lawyers in a country. In the CEPEJ reports, a lawyer is defined as "... a person qualified and authorized according to the national law to plead and act on behalf of his or her clients, to engage in the practice of law, to appear before the courts or advise and represent his or her clients in legal matters" (CEPEJ 2014). We use the number of lawyers per 10,000 inhabitants.

Figure 3 shows the number of lawyers per 10,000 inhabitants in 2014 in each of the countries included in our sample. Again, significant discrepancies exist between the different countries. Remarkably, the number of lawyers increases for each country between 2006 and 2014 (see Figure 4). Even in countries where the lawyer 
density was already considerable, the increase is significant. For example, Italy had 29 lawyers per 10,000 inhabitants in 2006 and 37 in 2014 (i.e. an increase of 27\%). The finding that many European countries have a high number of lawyers and that this number is increasing in almost each of them, raises the question whether this evolution is affecting litigation rates. We empirically investigate this hypothesis in Section 4.

\section{[Insert Figure 3 here]}

[Insert Figure 4 here]

\section{Control variables}

Our model includes the (natural logarithms of) following controls: population, population density, number of judges, legal aid, GDP per capita, change in GDP per capita, number of courts, congestion, use of contingency fees and availability of legal insurance. ${ }^{6}$

Following Buonanno and Galizzi (2014) and D'Agostino, Sironi, and Sobbrio (2012), we include population density as a control to proxy the average concentration of population. It is hypothesized that in more densely populated countries the number of social interactions, and hence, the potential for conflicts is higher.

The number of judges per 10,000 inhabitants is included as a proxy for productivity of the courts (Buonanno and Galizzi 2014, Ginsburg and Hoetker 2006), and therefore we expect that more judges increase litigation rates.

Legal aid lowers the costs of filing a suit and presumably induces litigation. In the CEPEJ reports, legal aid is defined as "aid given by the State to persons who

\footnotetext{
${ }^{6}$ Because they are time-invariant, use of contingency fees and availability of legal insurance are only used in models without country fixed effects.
} 
do not have sufficient financial means to defend themselves before a court (or to initiate a court proceeding). [...] However, legal aid consists also in legal advice" (CEPEJ 2008). Thus, legal aid is defined in a broad sense and not only includes financial help to initiate court proceedings and hire legal representation, but also includes financial aid for legal advice. The latter comprises information policies and mechanisms to stimulate parties in preventing trials. The two components of legal aid (i.e. lowering litigation costs and stimulating alternative dispute resolution) make it difficult to predict its effect on the demand for civil trials. On the one hand, legal aid reduces the financial burdens of filing a suit and thus induces litigation. On the other hand, legal advice enhances parties' realistic assessment of winning probabilities, hence encouraging alternative dispute resolution. Consequently, the net effect of legal aid on litigation rates cannot be predicted unambiguously ex ante.

The impact of GDP per capita on litigation has been examined in previous studies (Clemenz and Gugler 2000, Mora-Sanguinetti and Garoupa 2015, Buonanno and Galizzi 2014), but the direction of the effect remains ambiguous. On the one hand, in wealthier countries, parties find it easier to fulfil obligations, fewer contracts are broken and creditors are presumably more patient. On the other hand, a higher GDP per capita not only implies a higher number of transactions but also more complex transactions, which in turn augments the potential for conflicts (Hanssen 1999, Posner 1997, Clemenz and Gugler 2000, Ginsburg and Hoetker 2006). Moreover, parties living in more prosperous regions can be presumed to have a higher ability to pay potential litigation costs (Sobbrio, D'Agostino and Sironi 2010). We also include the growth rate of GDP per capita to take into account economic cycles. We expect that negative growth rates are associated with higher litigation rates since contracts are more likely to be broken (Carmignani and Giacomelli 2010, Ginsburg and Hoetker 2006, Clemenz and Gugler 2000). 
Since the availability of courts is very likely to affect litigation, we also include the number of courts per million inhabitants. Because the proximity of a court reduces the costs of going to trial, relatively more courts will presumably increase litigation. This implies a positive relation between courts and litigation. However, relatively less courts could be an indication of larger courts where specialization and economies of scale increase efficiency. Then, the more efficient courts presumably attract more cases (since cases are likely to be resolved more expeditiously) and hence a negative relation exists between the number of courts and the demand for justice.

When courts are backlogged, alternative dispute resolution (such as settlement) becomes a more appealing option than filing suit (Murrell 2001). Therefore, we expect a negative relationship between court congestion and litigation rates. To measure backlogs, we use the number of pending cases per judge.

We also include a dummy that equals one if contingency fees are allowed in the observed country. Many authors have argued that contingency fee contracts enable plaintiffs with limited resources to secure otherwise unaffordable costs, and therefore the availability of contingency fees increases access to courts (Rubinfeld and Scotchmer 1993, Brickman 2003, Zamir and Ritov 2010). Furthermore, scholars have argued that lawyers' exploitation of their informational advantage is more common when lawyers are paid per legal act or on an hourly basis (Emons 2000, Polinsky and Rubinfeld 2003). Following the existing literature, we hypothesize that the litigation rates are higher, ceteris paribus, in countries where lawyers are allowed to use contingency fees.

Finally, we control for the availability of legal insurance, since the latter increases access to justice. That is, we expect (all else equal) that countries in which legal insurance is available, litigation rates will be on average higher. 
Since the availability of legal insurance and contingency fees are time-invariant over our timespan, we can only include them in our models that do not control for country fixed effects.

\section{Empirical strategy and results}

We use different empirical strategies to estimate variations of equation (1). In all models, both our dependent and independent variables are logged ${ }^{7}$ to facilitate the interpretation of coefficients as elasticities, to achieve more normal distributions on the left- and right-hand side of the equation and to mitigate the effect of outliers. Standard errors are always heteroscedasticity-robust (White 1980) and clustered at the country level to correct for a possible correlation of error terms over time for all countries (Newey and West 1987).

\section{Benchmark: Pooled OLS}

First, we estimate the following models using pooled OLS:

$\log \left(\right.$ Litigation $_{\mathrm{it}}=\alpha+\beta \log (\text { Lawyers })_{\mathrm{it}}+\sum_{\mathrm{c}=1}^{10} \log (\text { Controls })_{\mathrm{it}}^{\mathrm{c}}+\mu_{i} \mathrm{t}+\sum_{\mathrm{t}=2}^{5} \gamma_{\mathrm{t}} \mathrm{D}_{\mathrm{t}}+\varepsilon_{\mathrm{it}}(2)$

Where $\alpha$ is the intercept and $\varepsilon_{i t}$ the error term for country $i$ in year t. The term $\mu_{i} t$ is a country-specific linear time trend and controls for unobserved country-specific trends in litigation rates. $\mathrm{D}_{\mathrm{t}}$ represent year dummies that control for year fixed effect and capture factors that vary over time but affect all countries (e.g. financial crisis effects).

We first estimate equation (2) without the year dummies, and subsequently without them. The results of the pooled OLS models are shown in columns (1) and

\footnotetext{
${ }^{7}$ With exception of Growth, which has negative values, and Congestion, which is measured as cases per judge.
} 
(2) of Table 3. Both estimations result in a statistically insignificant impact of Lawyers on Litigation. As discussed in section 2, however, unobserved heterogeneity is plausible since countries are assumed to differ in terms of (legal) culture, legal origin, availability of alternative dispute resolution, etc. Some of these differences remain unobserved, but are correlated with the observed independent variables, and consequently the pooled OLS-regressions yield biased estimations of $\beta$, the effect of Lawyers on Litigation. Therefore, we now address this omitted variable bias concern by applying a panel fixed effects approach.

\section{Fixed effects estimation}

To tackle the possible endogeneity problem arising from omitted variables in our panel dataset, we estimate a two-way fixed effects model in the following form:

$\log (\text { Litigation })_{\mathrm{it}}=\alpha_{\mathrm{i}}+\gamma_{\mathrm{t}}+\beta \log (\text { Lawyers })_{\mathrm{it}}+\sum_{\mathrm{c}=1}^{10} \log (\text { Controls })_{\mathrm{it}}^{\mathrm{c}}+\alpha_{\mathrm{i}} \mathrm{t}+\mathrm{u}_{\mathrm{it}}$

In equation (3) $\alpha_{\mathrm{i}}$ is the country fixed effect, which measures the time-invariant unobserved country-specific heterogeneity such as legal culture or legal origin. $\gamma_{t}$ represents the year fixed effect (the equivalent of the set of time dummies in equation (2)), i.e. the time-varying effects that are uniform across countries. $\alpha_{\mathrm{i}} \mathrm{t}$ is a linear country-specific time trend and $u_{i t}$ is the error term.

One important note is that in our dataset, the number of lawyers changes significantly between 2006 and 2014 (see Table 2 and Figure 4) and is therefore not subsumed in the fixed effects.

The estimation results are presented in column (3) of Table 3. With the inclusion of the country fixed effects, the effect of Lawyers on Litigation remains statistically insignificantly different from zero.

Although our two-way fixed effects model takes into account the unobserved and time-invariant heterogeneity, it does not tackle the plausible reverse causality 
between Lawyers and Litigation and possible time-varying country-heterogeneity. Therefore, we apply several instrumental variable approaches in the next Section.

\section{Addressing endogeneity: 2SLS instrumental variable estimation}

As discussed, the relationship between Lawyers and Litigation may be affected by reverse causality because lawyers not only induce litigation, but additional litigation will also attract more lawyers. To address this simultaneity bias, we first apply a 2 SLS approach.

In this paper, we separately use two instruments for the endogenous covariate Lawyers. First, we follow Mora-Sanguinetti and Garoupa (2015) and Buonanno and Galizzi (2014) and use the number of law schools. More precisely, we use the number of law schools that exists in each country, and relate this number to the country's surface. ${ }^{8}$ This instrument is expected to be correlated with the number of lawyers in a country, since a higher law school density captures the presence of a tradition for legal studies (which promotes the development of the lawyer profession) (Carmignani and Giacomelli 2010). Furthermore, educational costs increase when the distance to a law school is higher. Therefore, the number of law schools per square kilometer presumably (positively) affects the number of lawyers in a country. Yet, the requirement that our instrument must be exogenous to changes in litigation rates may not be satisfied since the number of law schools in a country is likely to be affected by the level of litigation. We address this issue by constructing the instrument with reference to a period that precedes the timespan of our dataset. Therefore, to ensure exogeneity of our instrument, we use the number of law schools in 1970 (i.e. 36 year prior to the beginning of our dataset).

\footnotetext{
${ }^{8}$ A list of law schools in Europe was gathered from HG.org, an online law and government information site, founded by Lex Mundi. The year of foundation of the law faculty was gathered from the official website of each university.
} 
The use of a time-invariant instrument (the number of law schools in 1970) prevents us from using country fixed effects. Although dropping the fixed effects would allow us to use the instrument to address the reverse causality issues, it would re-introduce endogeneity in the form of unobserved and time-invariant countryheterogeneity. Therefore, we follow Mora-Sanguinetti and Garoupa (2015) and include regional fixed effects ${ }^{9}$ (which allows us to use the law school instrument) and include as controls the average of each control to account for country-specific unobserved heterogeneity:

$\log (\text { (Litigation })_{\mathrm{it}}=\beta \log (\text { (Lawyers })_{\mathrm{it}}+\sum_{\mathrm{c}=1}^{10} \log (\text { Controls })_{\mathrm{it}}^{\mathrm{c}}+\sum_{\mathrm{c}=1}^{10} \overline{\log (\text { Controls })_{\mathrm{t}}^{\mathrm{c}}}+\alpha_{\mathrm{r}}+\delta_{\mathrm{t}}+\alpha_{\mathrm{r}} \mathrm{t}+\mathrm{u}_{\mathrm{it}}$

Where $\alpha_{\mathrm{r}}$ are region fixed effects and $\alpha_{\mathrm{r}} \mathrm{t}$ region-specific time trends.

The 2SLS results where Lawyers is instrumented by the number of law schools per square kilometer in 1970 are presented in columns (1) and (2) of Table 4. Both with and without the inclusion of the time trends, we find a positive and statistically significant effect of Lawyers on Litigation. All else equal, a 1 percent increase in Lawyers increases Litigation, on average, with 1.46 to 1.47 percent.

As discussed extensively in literature (see, e.g. Stock and Yogo 2005, Staiger and Stock 1994), instruments can be weak in the sense that they are satisfactorily exogenous, but only weakly correlated with the endogenous covariate. In that case, "the cure can be worse than the disease" (Bound, Jaeger and Baker 1993). Therefore, we first evaluate the goodness-of-fit of the first stage results as a way to examine whether the excluded instrument is sufficiently correlated with the included endogenous regressor. ${ }^{10}$ According to Staiger and Stock (1994), an F statistic of less than 10 in the first stage of the two-stage procedure suggests a weak instrument. Nevertheless, smaller F values are acceptable as well in our case since we have a just-identified model with one endogenous variable and one instrument.

\footnotetext{
${ }^{9}$ We grouped countries into 4 categories: North, East, South and West-Europe.

${ }^{10}$ The first stage results are omitted because of space considerations. The results are available upon request.
} 
This is true because in case of just-identified models, 2SLS is median-unbiased (Angrist and Pischke 2009, Mocan and Cannonier 2016). However, with F-values of 13.19 and 11.99 respectively, we can convincingly reject the hypothesis that our instrument is weak.

To test the robustness of our results and to overcome the suboptimal strategy of including regional fixed effects instead of country fixed effects in the presence of a time-invariant instrument, we propose a second instrument. More specifically, we construct an instrument that measures the number of law graduates (related to population). ${ }^{11} \mathrm{We}$ expect that an increase in the number of law graduates induces the number of lawyers in a country. Although not every law graduate will enter the lawyer profession, at least a significant fraction will. Nonetheless, as with our law school instrument, the requirement that our instrument must be exogenous to changes in litigation rates may not be satisfied. Higher litigation rates could motivate individuals to pursue an education in law and hence a higher number of law graduates can be expected. Therefore, we lag the number of graduates with two years. ${ }^{12}$ However, the instrument turns out to be very weak: the F-statistic of the excluded instrument is only 0.37 . The results are presented in column (3) of Table 4.

\section{Addressing endogeneity: GMM instrumental variable estimation}

As a second strategy, we use the GMM difference estimator to tackle reverse causality between Lawyers and Litigation. Checking the robustness of our results with GMM is particularly appealing because in our first 2SLS estimation (results

\footnotetext{
${ }^{11}$ The data were gathered from the OECD (statistics on Education and Training - Graduates by field of education) and from National Statistical Offices for the non-OECD countries.

${ }^{12}$ A lag of two years may not seem a considerable amount of time, but note that we are looking at law graduates, and not newly registered law students. Hence, the decision to start a law school program from graduates in year $\mathrm{t}$ was made in year $\mathrm{t}-\mathrm{x}$ ( $\mathrm{x}$ being the number of years of law education). Furthermore, we re-ran our regressions and lagged graduates with 4 years. Results were qualitatively the same but the sample reduced in size due to data limitations.
} 
in column (1) and (2) of Table 4) we had to rely on region FE rather than country FE and because of the weakness of the instrument used in the second 2SLS estimation (results in column (3) of Table 4).

The GMM difference approach, developed by Arellano and Bond (1991), starts by first-differencing the equation, thus removing the unobserved individual effect $\alpha_{\mathrm{i}}$ (Baum 2006). Subsequently, the equation is estimated using the standard GMM procedure (hence the name "difference GMM") (Hansen and Singleton 1982). The rationale of Arellano-Bond estimation is drawn on instruments from within the dataset, rather than using external instruments that might be weak (such as our law graduates instrument). Although it is possible to use lagged regressors as instruments with standard 2SLS, the use of deeper lags reduces sample size since observations for which lagged observations are unavailable are dropped. Yet GMM eliminates the trade-off between lag depth and sample size, rendering it possible to include all valid lags of the untransformed variables as instruments (Roodman 2009).

One pitfall of the Arellano-Bond approach is the overfitting of endogenous variables when using a large instrument set. Although there is little guidance from literature on the maximum number of instruments, Roodman (2009) suggest to collapse the used instrument set.

The GMM results are presented in column (4) of Table 4. The results again suggest a positive and statistically significant impact of Lawyers on Litigation, confirming the lawyer-induced litigation hypothesis. A one percent increase in Lawyers, increases Litigation with on average 1.16 percent, all else equal.

Finally, we evaluate the consistency of the difference GMM estimator. To test the validity of our internal instruments, we use both the Hansen test of overidentifying restrictions and the Arellano-Bond test for serial correlation of the error term. As reported in Table 4, these tests confirm the validity of our instrument set. 


\section{Robustness check}

To further test the validity of our results, we perform an additional analysis. We hypothesize that a positive relationship exists between litigation rates and lawyer density because lawyers deliberately induce litigation when competition is though. If this is true, then lawyer density should not impact criminal litigation, since lawyers have no say in the decision to file a criminal suit (this is the competence of the public prosecutor). In other words, if we re-estimate our models and replace the dependent variable (number of new civil cases per 10,000 inhabitants) with the number of criminal cases per 10,000 inhabitants, ${ }^{13}$ we should not find a positive and statistically significant impact of Lawyers. Otherwise, something else than the supplier induced demand phenomenon might be causing a positive relationship between Lawyers and Litigation. Table 5 shows the results. In none of the models Lawyers is statistically significantly different from zero. The results of this placebo test add to the credibly of our empirical results and the conclusions we have drawn, namely that an increase in the number of lawyers increases civil litigation because lawyers induce litigation. Given that Lawyers is not statistically significant in the crime models, we believe that this result is not a consequence of coincidence.

\section{Conclusion and discussion}

Economic theory predicts that an overabundance of lawyers induces litigation. Hence, both successful regulation of the lawyer profession and effective policy measures that discourage frivolous lawsuits require a thorough understanding of the relationship between the number of lawyers and the litigation rate in a country. However, empirically examining the relationship between lawyers and litigation is

\footnotetext{
${ }^{13}$ Of course, we also replace the number of pending civil cases by the number of pending criminal cases.
} 
challenging because of endogeneity problems. Since it is difficult to find appropriate instruments, empirical evidence remains scarce.

To analyze the effect of the number of lawyers on litigation rates, this paper uses biennial homogeneous data on the functioning of the judicial systems of 30 member states of the European Council in the period 2006-2014. We explicitly tackle the problem of reverse causality between lawyers and litigation using several estimation strategies.

First, we use a 2SLS approach. From a theoretical point of view, both the number of law schools per square kilometer and the number of law graduates per 10,000 inhabitants in a country are expected to be valid instruments. Both should be highly correlated with the number of lawyers and uncorrelated with unobserved factors affecting litigation rates. Since we require an exogenous source of variation for the number of lawyers, we lag the instruments. The 2SLS estimations with law schools as an instrument yield results that are in line with the supplier induced demand hypothesis: the number of lawyers has a positive and statistically significant impact on litigation rate. The number of law graduates appears to be a weak instrument and therefore we cannot rely on the estimation results.

As an alternative approach, we tackle the anticipated reverse causality between lawyers and litigation using the linear GMM (General Method of Moments) estimator of Arellano and Bond (1991). Again, we find a positive and significant effect of lawyer density on litigation rate.

A major policy implication of our empirical results is that a desired moderation of the growing litigiousness in Europe should be associated with incentives that restrain lawyers from exploiting their informational advantage. For example, Emons (2000) and Polinsky and Rubinfeld (2003) show that lawyers' exploitation of their informational advantage is more common when lawyers are paid per legal act or on an hourly basis (as is most common in continental Europe). Contingency fees, on the contrary, are dependent upon the outcome of the trial and provide an 
incentive for lawyers to take on cases with a realistic chance of winning. In that regard, policymakers might want to reconsider strongly regulated lawyers' remunerations and the prohibition of the use of contingency fees that are in effect in most European countries (European Commission 2004). ${ }^{14}$ Furthermore, the evidence of the lawyer-induced litigation hypothesis might even call for a numerus clausus to limit the number of law students. In some health care systems, for example, a numerus clausus limits the number of physicians that may practice under the national health insurance system. The decision to introduce such a restriction is motivated by concerns about health care expenditures (driven by supplier induced demand) and quality of care (see, e.g. Belgian Health Care Knowledge Centre 2008). Similarly, a restriction on the number of lawyers should prevent lawyer-induced litigation, with less lawsuits as a result. Consequently, we expect a decline of expenditures related to both legal aid and court congestion. On the other hand, too few lawyers will lead to increased lawyer fees, which will hamper access to the courts. Therefore, it is crucial to find the optimal number of lawyers, which can differ from one judiciary to the other.

\footnotetext{
${ }^{14}$ For example, contingency fees are allowed by law in only 37 percent of the OECD countries (Palumbo et al. 2013).
} 


\section{REFERENCES}

Angrist, Joshua D and Jörn-Steffen Pischke. 2009. Mostly harmless econometrics: An empiricist's companion: Princeton university press.

Arellano, Manuel and Stephen Bond. 1991. "Some Tests of Specification For Panel Data: Monte Carlo Evidence and an Application To Employment Equations." The Review of Economic Studies, 58:2, 277-297

Baum, Christopher F. 2006. An Introduction to Modern Econometrics Using Stata. Texas: Stata Press.

Baum, Christopher F, Mark E Schaffer and Steven Stillman. 2003. "Instrumental variables and GMM: Estimation and testing." Stata journal, 3:1, 1-31

Beale, Sara Sun. 1994. "Too Many and Yet Too Few: New Principles to Define the Proper Limits for Federal Criminal Jurisdiction." Hastings Law Journal, 46:1, 979-108

Belgian Health Care Knowledge Centre. 2008. Physician Workforce Supply in Belgium. Current Situation and Challenges. KCE Reports 72C

Bielen, Samantha, Wim Marneffe and Lode Vereeck. 2015. "Litigation decision." In Encyclopedia of Law and Economics, edited by Jürgen Backhaus, Alain Marciano and Giovanni B Ramello. New York: Springer.

Birch, Stephen. 1988. "The Identification of Supplier-inducement in a Fixed Price System of Health Care Provision: The Case of Dentistry in the United Kingdom." Journal of Health Economics, 7:2, 129-150

Bound, John, David A Jaeger and Regina Baker. 1993. The Cure Can Be Worse Than the Disease: A Cautionary Tale Regarding Instrumental Variables. NBER Technical Working Paper No. 137.

Brickman, Lester. 2003. "Effective Hourly Rates of Contingency-Fee Lawyers: Competing Data and Non-Competitive Fees." Washington University Law Review, 81:3, 653-736

Buonanno, Paolo and Matteo M. Galizzi. 2014. "Advocatus, et non Latro? Testing the Excess of Litigation in the Italian Courts of Justice." Review of Law and Economics, 10:3, 285-322

Buscaglia, Edgardo and Maria Dakolias. 1999. Comparative International Study of Court Performance Indicators: A Descriptive and Analytical Account: World Bank.

Carmignani, Amanda and Silvia Giacomelli. 2010. "Too Many Lawyers?: Litigation in Italian Civil Courts." Bank of Italy Temi di Discussione (Working Paper) No. 745,

CEPEJ. 2008. European Judicial Systems. Editions 2008 (2006 Data). Efficiency and Quality of Justice. Strasbourg: Council of Europe Publishing.

CEPEJ. 2010. European Judicial Systems. Editions 2010 (2008 Data). Efficiency and Quality of Justice. Strasbourg: Council of Europe Publishing. 
CEPEJ. 2012. European Judicial Systems. Editions 2012 (2010 Data). Efficiency and Quality of Justice. Strasbourg: Council of Europe Publishing.

CEPEJ. 2014. European Judicial Systems. Editions 2014 (2012 Data). Efficiency and Quality of Justice. Strasbourg Council of Europe Publishing.

CEPEJ. 2016. European Judicial Systems. Editions 2016 (2014 Data). Efficiency and Quality of Justice. Strasbourg Council of Europe Publishing.

Clemenz, Gerhard and Klaus Gugler. 2000. "Macroeconomic Development and Civil Litigation." European Journal of Law and Economics, 9:3, 215-230

Cooter, Robert D. and Thomas Ulen. 2013. Law and Economics. New Jersey: Pearson Education.

D'Agostino, Elena, Emiliano Sironi and Giuseppe Sobbrio. 2012. "Lawyers and Legal Disputes. Evidence from Italy." Applied Economics Letters, 19:14, 1349-1352

Dimitrova-Grajzl, Valentina, Peter Grajzl, Atanas Slavov and Katarina Zajc. 2016. "Courts in a Transition Economy: Case Disposition and the Quantityquality Tradeoff in Bulgaria." Economic Systems, 40:1, 18-38

Emons, Winand. 2000. "Expertise, Contingent Fees, and Insufficient Attorney Effort." International Review of Law and Economics, 20:1, 21-33

European Commission. 2004. Study on the Conditions of Claims for Damages in Case of Infringement of EC Competition Rules. Brussels.

Felli, Ernesto L, David Andres Londoñ-Bedoya, Nazaria Solferino and Giovanni Tria. 2008. "The "Demand for Justice" in Italy: Civil Litigation and the Judicial System." In Italian Institutional Reforms: A Public Choice Perspective, edited by Fabio Padovano and Roberto Ricciuti, 155-177. New York: Springer.

Fuchs, Victor. 1978. "The supply of surgeons and the demand for operations." $J$ Hum Resour, 13:35-56

Garoupa, Nuno. 2008. "Providing a Framework for Reforming the Legal Profession: Insights From the European Experience." European Business Organization Law Review, 9:3, 463-495

Geyh, Charles G. 1993. "Adverse Publicity As a Means of Reducing Judicial Decision-Making Delay: Periodic Disclosure of Pending Motions, Bench Trials and Cases Under the Civil Justice Reform Act." Cleveland State Law Review, 41:511, 511-536

Ginsburg, Tom; and Glenn Hoetker. 2006. "The Unreluctant Litigant? An Empirical Analysis of Japan's Turn to Litigation." The Journal of Legal Studies, 35:1, 31-59

Gould, John P. 1973. "The Economics of Legal Conflicts." The Journal of Legal Studies, 2:2, 279-300 
Grajzl, Peter and Peter Murrell. 2005. "Allocating Lawmaking Powers: SelfRegulation vs Government Regulation." Journal of Comparative Economics, 35:3, 520-545

Grytten, Jostein, Fredrik Carlsen and Rune Sørensen. 1995. "Supplier inducement in a public health care system." Journal of Health Economics, 14:2, 207229

Haig, Robert L.; and Warren N. Stone. 1993. "The Civil Justice Reform Act: Does all this Litigation "Reform" Really Benefit the Client?" St. John's Law Review, 67:4, 843-875

Hansen, Lars Peter and Kenneth J Singleton. 1982. "Generalized Instrumental Variables Estimation of Nonlinear Rational Expectations Models." Econometrica: Journal of the Econometric Society, 50:5, 1269-1286

Hanssen, F Andrew. 1999. "The Effect of Judicial Institutions on Uncertainty and the Rate of Litigation: The Election Versus Appointment of State Judges." The Journal of Legal Studies, 28:1, 205-232

Hellerstein, Judith K. 1998. "The Importance of the Physician in the Generic Versus Trade-Name Prescription Decision." The Rand journal of economics, 29:1, $108-136$

Johnson, Carrie E. . 1997. "Rocket Dockets: Reducing Delay in Federal Civil Litigation." California Law Review, 85:1, 225-264

Landes, William M. 1971. "An Economic Analysis of the Courts." Journal of Law and Economics, 14:1, 61-108

Mocan, Naci and Colin Cannonier. 2016. "The Impact of Education on Women's Preferences for Gender Equality: Evidence from Sierra Leone." Journal of Demographic Economics (forthcoming),

Mora-Sanguinetti, Juan S and Nuno Garoupa. 2015. "Do Lawyers Induce Litigation? Evidence From Spain, 2001-2010." International Review of Law and Economics, 44:2015, 29-41

Murrell, P. 2001. Demand and Supply in Romanian Commercial Courts: Generating Information for Institutional Reform. Maryland: IRIS Center.

Nelken, David. 2004. "Using the Concept of Legal Culture." Australian Journal of Legal Philosophy, 29:1, 1-26

Newey, Whitney K and Kenneth D West. 1987. "A Simple, Positive Semi-definite, Heteroskedasticity and Autocorrelationconsistent Covariance Matrix." Econometrica: Journal of the Econometric Society, 55:3, 703-708

North, Douglass C. 1990. Institutions, Intitutional Change and Economic Performance. Cambridge: Cambridge University Press.

Palumbo, Giuliana, Giulia Giupponi, Luca Nunziata and Juan S Mora Sanguinetti. 2013. The Economics of Civil Justice: New Cross-Country Data and Empirics. OECD Economics Department Wokring Papers No. 1060. 
Peters, Michael, Malte Schneider, Tobias Griesshaber and Volker H Hoffmann. 2012. "The Impact of Technology-Push and Demand-Pull Policies on Technical Change-Does the Locus of Policies Matter?" Research Policy, 41:8, 1296-1308

Polinsky, A Mitchell and Daniel L Rubinfeld. 2003. "Aligning the Interests of Lawyers and Clients." American Law and Economics Review, 5:1, 165-188

Posner, Richard A. 1973. "An Economic Approach to Legal Procedure and Judicial Administration." The Journal of Legal Studies, 2:2, 399-458

Posner, Richard A. 1997. "Explaining the Variance in the Number of Tort Suits across US States and between the United States and England." Journal of Legal Studies 26:S2, 477-489

Posner, Richard A. 1998. "Creating a Legal Framework for Economic Development." The World Bank Research Observer, 13:1, 1-11

Posner, Richard A. 2014. Economic Analysis of Law. New York: Wolters Kluwer Law and Business.

Ramello, Giovanni B and Stefan Voigt. 2012. "The Economics of Efficiency and the Judicial System." International Review of Law and Economics, 32:1, 12

Robel, Lauren K. 1992. "Private Justice and the Federal Bench." Indian Law Journal, 68:3, 891-906

Romano, Richard E. 1994. "Double Moral Hazard and Resale Price Maintenance." The RAND Journal of Economics, 25:3, 455-466

Roodman, David. 2009. "How to do Xtabond2: An Introduction to Difference and System GMM in Stata." Stata Journal, 9:1, 86-136

Roussey, Ludivine and Bruno Deffains. 2012. "Trust in Judicial Institutions: An Empirical Approach." Journal of Institutional Economics, 8:03, 351-369

Rubinfeld, Daniel F and Suzanne Scotchmer. 1993. "Contingent Fees for Attorneys: An Economic Analysis." RAND Journal of Economics, 24:3, 343-356

Sobbrio, Giuseppe, Elena D'Agostino and Emiliano Sironi. 2010. "New Disputes and Delay in Italian Courts." Paolo Baffi Centre Research Paper, 2010-84

Staiger, Douglas O and James H Stock. 1994. "Instrumental Variables Regression With Weak Instruments." Econometrica, 65:3, 557-586

Stock, James H and Motohiro Yogo. 2005. "Testing for Weak Instruments in Linear IV Regression." In Identification and inference for econometric models: Essays in honor of Thomas Rothenberg, edited by Donald W.K. and James H. Stock (Eds.) Andrews, 80-108. Cambridge University Press.

Westover, Harry C. 1958. "The Cause, Effect and Solution of Congestion in the Federal Courts." Hastings Law Journal, 10:1, 384-393 
White, Halbert. 1980. "A Heteroskedasticity-consistent Covariance Matrix Estimator and a Direct Test for Heteroskedasticity." Econometrica: Journal of the Econometric Society, 48:4, 817-838

Yates, Jeff, Belinda Creel Davis and Henry R Glick. 2001. "The Politics of Torts: Explaining Litigation Rates in the American States." State Politics and Policy Quarterly, 1:2, 127-143

Zamir, Eyal and Ilana Ritov. 2010. "Revisiting the Debate over Attorneys' Contingent Fees: A Behavioral Analysis." The Journal of Legal Studies, $39: 1,245-288$

Zhou, Jun. 2008. "Determinants of Delay in Litigation: Evidence and Theory." American Law \& Economics Association Papers, 1-27 
TABLE 1: VARIABLE DESCRIPTION

\begin{tabular}{ll}
\hline \hline Variable & Description \\
\cline { 1 - 2 } $\begin{array}{l}\text { Litigation } \\
\text { Lawyers }\end{array}$ & Number of incoming civil (and commercial) litigious cases at first instance courts. \\
Population & Number of lawyers, per 10,000 inhabitants. \\
Density & Number of inhabitants. \\
Judges & Number of judges, per 10,000 inhabitants \\
Legal aid & Annual public budget allocated to legal aid (€), per 10,000 inhabitants. \\
GDP & GDP per capita. \\
Growth & Change in GDP per capita. \\
Courts & Number of courts, per million inhabitants. \\
Congestion & Number of pending civil (and commercial) litigious cases at first instance courts, per judge. \\
Contingency & Dummy equal to one if contingency fees are allowed. \\
Insurance & Dummy equal to one if private system of legal expense insurance exists. \\
\hline \hline
\end{tabular}


TABLE 2: SUMMARY STATISTICS

\begin{tabular}{|c|c|c|c|c|c|}
\hline Variable & No. Obs. & Mean & Std. Dev. & Min. & Max. \\
\hline \multicolumn{6}{|l|}{ Litigation } \\
\hline Overall & $\mathrm{N}=130$ & 227.57 & 148.53 & 15.03 & 685.16 \\
\hline Between & $\mathrm{n}=30$ & & 137.78 & 18.90 & 493.20 \\
\hline Within & $\mathrm{T}=3.71$ & & 66.33 & 6.94 & 455.43 \\
\hline \multicolumn{6}{|l|}{ Lawyers } \\
\hline Overall & $\mathrm{N}=130$ & 11.27 & 8.47 & 0.64 & 38.07 \\
\hline Between & $\mathrm{n}=30$ & & 8.85 & 0.82 & 37.51 \\
\hline Within & $\mathrm{T}=3.71$ & & 1.63 & 5.28 & 18.19 \\
\hline \multicolumn{6}{|c|}{ Population (in millions) } \\
\hline Overall & $\mathrm{N}=130$ & 18.40 & 2.70 & 0.08 & 143.00 \\
\hline Between & $\mathrm{n}=30$ & & 3.10 & 0.08 & 143.00 \\
\hline Within & $\mathrm{T}=3.71$ & & 0.40 & 1.67 & 19.90 \\
\hline \multicolumn{6}{|l|}{ Density } \\
\hline Overall & $N=130$ & & 160.38 & 8.30 & $1,316.76$ \\
\hline Between & $\mathrm{n}=30$ & 115.21 & 215.97 & 8.34 & $1,304.65$ \\
\hline Within & $\mathrm{T}=3.71$ & & 2.59 & 103.10 & 128.333 \\
\hline \multicolumn{6}{|l|}{ Judges } \\
\hline Overall & $\mathrm{N}=130$ & 1.97 & 1.03 & 0.57 & 5.35 \\
\hline Between & $\mathrm{n}=3$ & & 1.07 & 0.62 & 4.91 \\
\hline Within & $\mathrm{T}=3.71$ & & 0.10 & 1.54 & 2.41 \\
\hline \multicolumn{6}{|l|}{ Legal aid } \\
\hline Overall & $\mathrm{N}=130$ & $49,768.87$ & $89,440.48$ & 67.07 & $535,540.1$ \\
\hline Between & $\mathrm{n}=30$ & & $84,311.90$ & 212.23 & $392,128.8$ \\
\hline Within & $\mathrm{T}=3.71$ & & $22,953.00$ & $-58,001.61$ & $193,180.10$ \\
\hline \multicolumn{6}{|l|}{ GDP } \\
\hline Overall & $\mathrm{N}=130$ & $19,821.40$ & $16,842.2$ & 745 & $79,235.00$ \\
\hline Between & $\mathrm{n}=30$ & & $16,234.34$ & $1,279.80$ & $66,190.80$ \\
\hline Within & $\mathrm{T}=3.71$ & & $2,478.26$ & $9,630.60$ & $32,865.60$ \\
\hline \multicolumn{6}{|l|}{ Growth } \\
\hline Overall & $N=130$ & 0.14 & 0.0 .25 & -0.30 & 1.53 \\
\hline Between & $\mathrm{n}=30$ & & 0.17 & -0.10 & 0.67 \\
\hline Within & $\mathrm{T}=3.71$ & & 0.20 & -0.33 & 1.34 \\
\hline \multicolumn{6}{|l|}{ Courts } \\
\hline Overall & $\mathrm{N}=130$ & 18.99 & 12.56 & 0.71 & 80.76 \\
\hline Between & $\mathrm{n}=30$ & & 11.25 & 0.71 & 47.41 \\
\hline Within & $\mathrm{T}=3.71$ & & 7.60 & -17.08 & 69.09 \\
\hline \multicolumn{6}{|l|}{ Congestion } \\
\hline Overall & $\mathrm{N}=130$ & 92.99 & 116.73 & 2.49 & 643.68 \\
\hline Between & $\mathrm{n}=30$ & & 112.56 & 7.69 & 578.04 \\
\hline Within & $\mathrm{T}=3.71$ & & 21.04 & 20.66 & 177.45 \\
\hline \multicolumn{6}{|l|}{ Contingency } \\
\hline Overall & $\mathrm{N}=130$ & 0.65 & 0.48 & 0 & 1 \\
\hline Between & $\mathrm{n}=30$ & & 0.49 & 0 & 1 \\
\hline Within & $\mathrm{T}=3.71$ & & 0 & 0.65 & 0.65 \\
\hline \multicolumn{6}{|l|}{ Insurance } \\
\hline Overall & $\mathrm{N}=130$ & 0.72 & 0.45 & 0 & 1 \\
\hline Between & $\mathrm{n}=30$ & & 0.40 & 0 & 1 \\
\hline Within & $\mathrm{T}=3.71$ & & 0.22 & -0.03 & 1.47 \\
\hline
\end{tabular}


TABLE 3: BASELINE REGRESSION RESULTS: POOLED OLS AND FIXED EFFECTS

\begin{tabular}{|c|c|c|c|}
\hline VARIABLES & $\begin{array}{c}(1) \\
\text { Pooled OLS }\end{array}$ & $\begin{array}{c}(2) \\
\text { Pooled OLS }\end{array}$ & $\begin{array}{c}\text { (3) } \\
\text { Fixed effects }\end{array}$ \\
\hline Lawyers & $\begin{array}{c}0.1674 \\
(0.1431)\end{array}$ & $\begin{array}{c}0.1542 \\
(0.1368)\end{array}$ & $\begin{array}{c}0.5672 \\
(0.3833)\end{array}$ \\
\hline Population & $\begin{array}{l}0.1398 * \\
(0.0698)\end{array}$ & $\begin{array}{l}0.1379 * \\
(0.0688)\end{array}$ & $\begin{array}{c}11.3263 \\
(25.5279)\end{array}$ \\
\hline Density & $\begin{array}{c}0.2753 * * \\
(0.1065)\end{array}$ & $\begin{array}{c}0.2721^{* *} \\
(0.1078)\end{array}$ & $\begin{array}{c}-10.5970 \\
(25.7107)\end{array}$ \\
\hline Judges & $\begin{array}{c}0.4612 * * * \\
(0.1262)\end{array}$ & $\begin{array}{c}0.4525 * * * \\
(0.1298)\end{array}$ & $\begin{array}{c}0.7104 \\
(0.4935)\end{array}$ \\
\hline Legal aid & $\begin{array}{c}0.0866 \\
(0.0647)\end{array}$ & $\begin{array}{c}0.0804 \\
(0.0642)\end{array}$ & $\begin{array}{c}0.1197 \\
(0.0841)\end{array}$ \\
\hline GDP & $\begin{array}{c}-0.0000 * * \\
(0.0000)\end{array}$ & $\begin{array}{c}-0.0000 * * \\
(0.0000)\end{array}$ & $\begin{array}{c}0.0000 \\
(0.0000)\end{array}$ \\
\hline Growth & $\begin{array}{c}0.5001 \\
(0.4326)\end{array}$ & $\begin{array}{c}0.3719 \\
(0.3599)\end{array}$ & $\begin{array}{l}-0.0227 \\
(0.1891)\end{array}$ \\
\hline Courts & $\begin{array}{c}0.2047 * * \\
(0.0896)\end{array}$ & $\begin{array}{c}0.2186 * * \\
(0.0979)\end{array}$ & $\begin{array}{l}-0.0797 \\
(0.0561)\end{array}$ \\
\hline Congestion & $\begin{array}{c}0.0016 * * \\
(0.0006)\end{array}$ & $\begin{array}{c}0.0016 * * \\
(0.0007)\end{array}$ & $\begin{array}{c}0.0069 * * * \\
(0.0015)\end{array}$ \\
\hline Contingency & $\begin{array}{c}0.1156 \\
(0.2448)\end{array}$ & $\begin{array}{c}0.1196 \\
(0.2416)\end{array}$ & \\
\hline Insurance & $\begin{array}{c}-0.2511 \\
(0.1792)\end{array}$ & $\begin{array}{c}-0.2539 \\
(0.1795)\end{array}$ & \\
\hline Observations & 118 & 118 & 130 \\
\hline Country FE & No & No & Yes \\
\hline Year FE & Yes & No & Yes \\
\hline Time trend & Yes & Yes & Yes \\
\hline
\end{tabular}


TABLE 4: IV-2SLS AND IV-GMM REGRESSION RESULTS

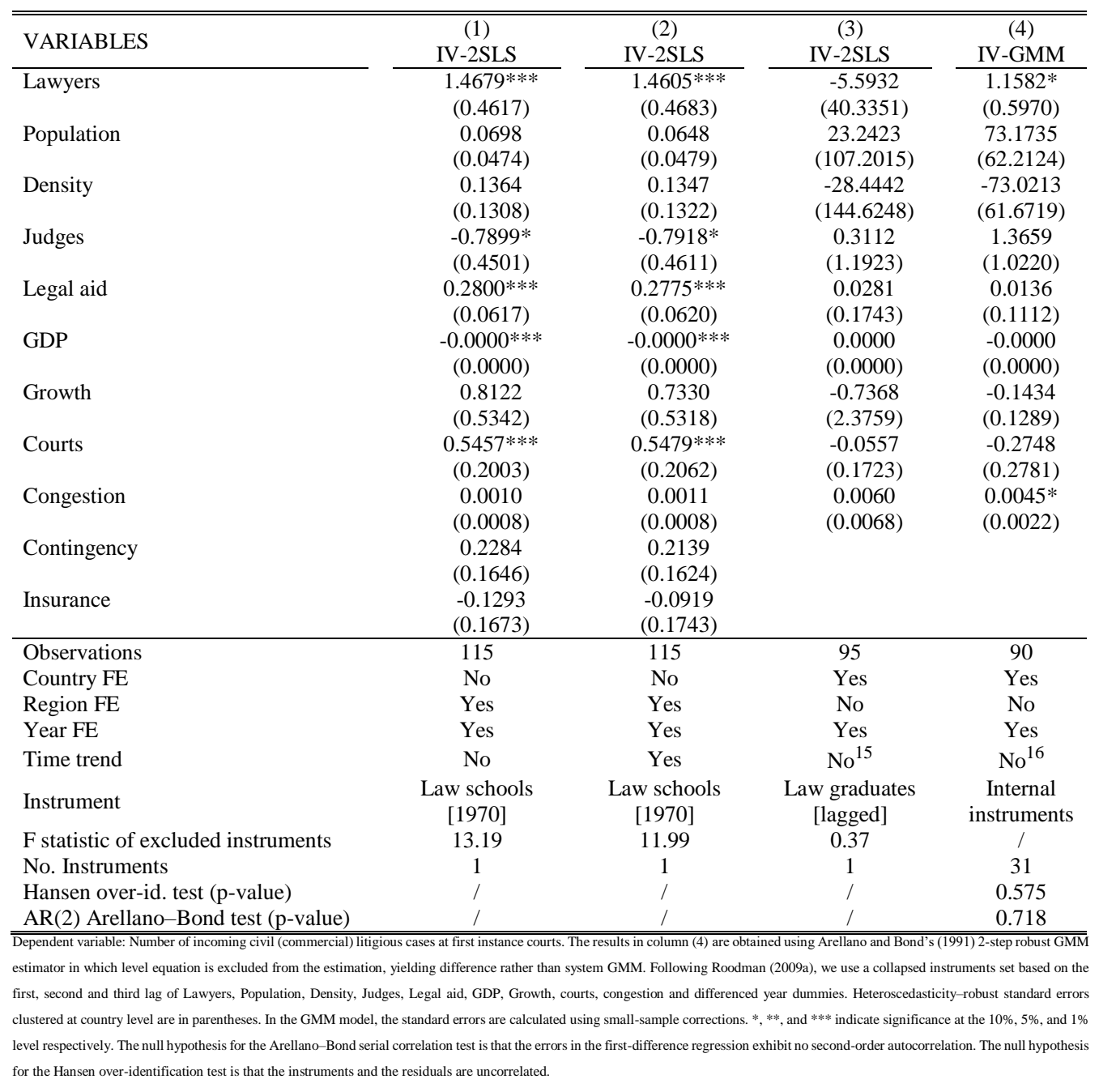

${ }^{15}$ Time trends are dropped because of collinearity.

${ }^{16}$ Time trends are dropped because of collinearity. 
TABLE 5: IV-2SLS AND IV-GMM REGRESSION RESULTS FOR CRIMINAL CASES

\begin{tabular}{|c|c|c|c|c|}
\hline VARIABLES & $\begin{array}{c}(1) \\
\text { IV-2SLS }\end{array}$ & $\begin{array}{c}(2) \\
\text { IV-2SLS }\end{array}$ & $\begin{array}{c}(3) \\
\text { IV-2SLS }\end{array}$ & $\begin{array}{c}(4) \\
\text { IV-GMM }\end{array}$ \\
\hline Lawyers & $\begin{array}{l}-1.8452 \\
(1.5107)\end{array}$ & $\begin{array}{l}-1.8260 \\
(1.4946)\end{array}$ & $\begin{array}{c}0.4322 \\
(1.9489)\end{array}$ & $\begin{array}{c}2.4140 \\
(2.6575)\end{array}$ \\
\hline Population & $\begin{array}{c}0.1950 * * \\
(0.0839)\end{array}$ & $\begin{array}{c}0.1923 * * \\
(0.0831)\end{array}$ & $\begin{array}{c}-113.9071^{*} \\
(63.1876)\end{array}$ & $\begin{array}{l}-194.1299 \\
(681.2119)\end{array}$ \\
\hline Density & $\begin{array}{l}-0.0823 \\
(0.3086)\end{array}$ & $\begin{array}{l}-0.0858 \\
(0.3031)\end{array}$ & $\begin{array}{c}115.1595^{*} \\
(60.3121)\end{array}$ & $\begin{array}{c}201.3834 \\
(681.6531)\end{array}$ \\
\hline Judges & $\begin{array}{c}2.7576 * * * \\
(0.8803)\end{array}$ & $\begin{array}{c}2.7538 * * * \\
(0.8711)\end{array}$ & $\begin{array}{c}0.7969^{* *} \\
(0.3711)\end{array}$ & $\begin{array}{c}1.0351 \\
(4.3831)\end{array}$ \\
\hline Legal aid & $\begin{array}{l}-0.1386 \\
(0.1497)\end{array}$ & $\begin{array}{l}-0.1401 \\
(0.1473)\end{array}$ & $\begin{array}{l}-0.0103 \\
(0.0625)\end{array}$ & $\begin{array}{c}0.0725 \\
(0.3232)\end{array}$ \\
\hline GDP & $\begin{array}{l}0.0001 * \\
(0.0000)\end{array}$ & $\begin{array}{l}0.0001 * \\
(0.0000)\end{array}$ & $\begin{array}{c}-0.0001 * * * \\
(0.0000)\end{array}$ & $\begin{array}{l}-0.0001 \\
(0.0001)\end{array}$ \\
\hline Growth & $\begin{array}{l}-1.2566 \\
(1.3359)\end{array}$ & $\begin{array}{l}-1.2734 \\
(1.3222)\end{array}$ & $\begin{array}{c}0.5503 \\
(0.3854)\end{array}$ & $\begin{array}{c}0.9163 \\
(1.7479)\end{array}$ \\
\hline Courts & $\begin{array}{l}-0.4957 \\
(0.3474)\end{array}$ & $\begin{array}{l}-0.5004 \\
(0.3438)\end{array}$ & $\begin{array}{l}-0.0645 \\
(0.0423)\end{array}$ & $\begin{array}{l}-0.1976 \\
(0.2182)\end{array}$ \\
\hline Congestion & $\begin{array}{c}0.0042 * * \\
(0.0021)\end{array}$ & $\begin{array}{c}0.0041 * * \\
(0.0021)\end{array}$ & $\begin{array}{c}0.0097 * * * * \\
(0.0013)\end{array}$ & $\begin{array}{c}0.0044 \\
(0.0097)\end{array}$ \\
\hline Contingency & $\begin{array}{l}-0.1016 \\
(0.3368)\end{array}$ & $\begin{array}{l}-0.1048 \\
(0.3320)\end{array}$ & & \\
\hline Insurance & $\begin{array}{c}0.2180 \\
(0.3958) \\
\end{array}$ & $\begin{array}{c}0.2149 \\
(0.3946) \\
\end{array}$ & & \\
\hline Observations & 76 & 76 & 64 & 55 \\
\hline Country FE & No & No & Yes & Yes \\
\hline Region FE & Yes & Yes & No & No \\
\hline Year FE & Yes & Yes & Yes & Yes \\
\hline Time trend & No & Yes & No & Yes \\
\hline Instrument & Law schools [1970] & Law schools [1970] & $\begin{array}{c}\text { Law graduates } \\
\text { [lagged] }\end{array}$ & $\begin{array}{c}\text { Set of internal } \\
\text { instruments }\end{array}$ \\
\hline
\end{tabular}




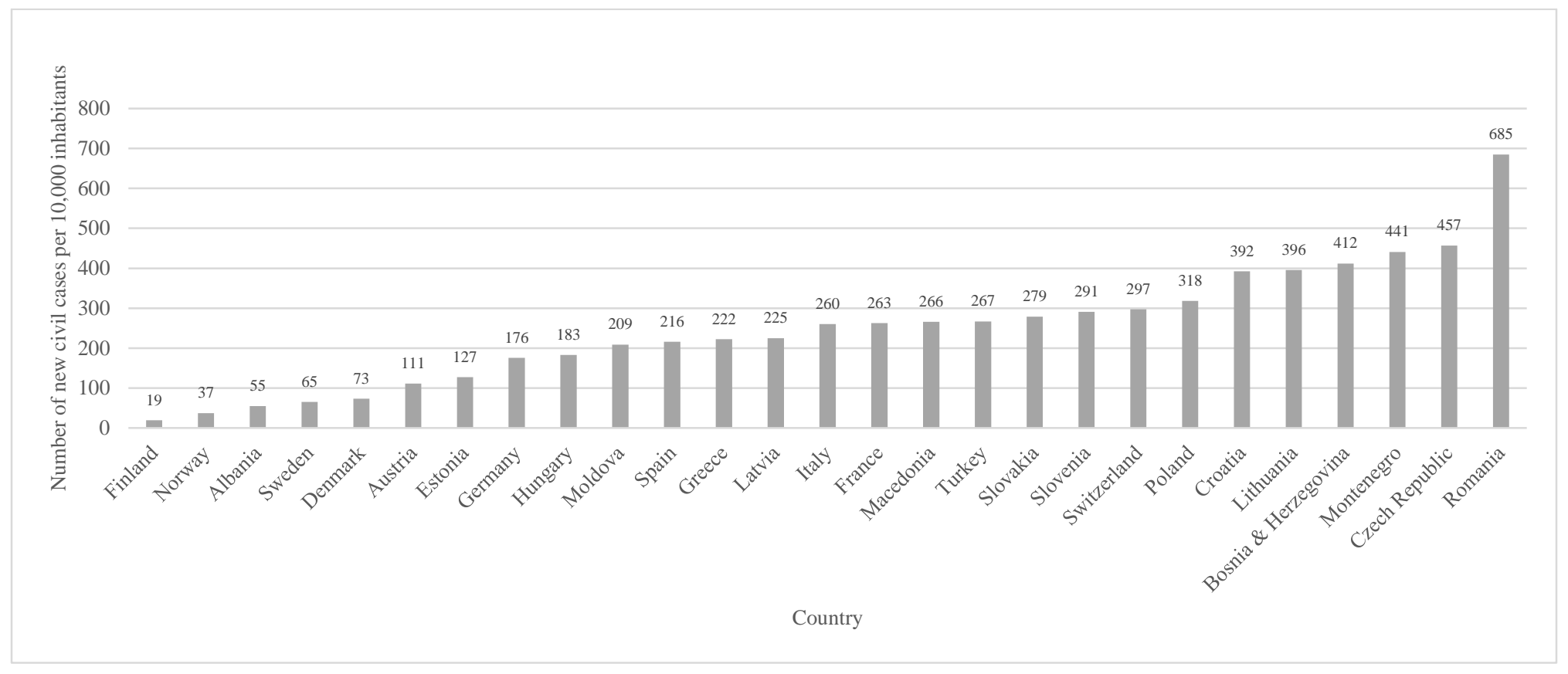




\section{FIGURE 2: TIME EVOLUTION OF LITIGATION RATES BETWEEN 2006 AND 2014}

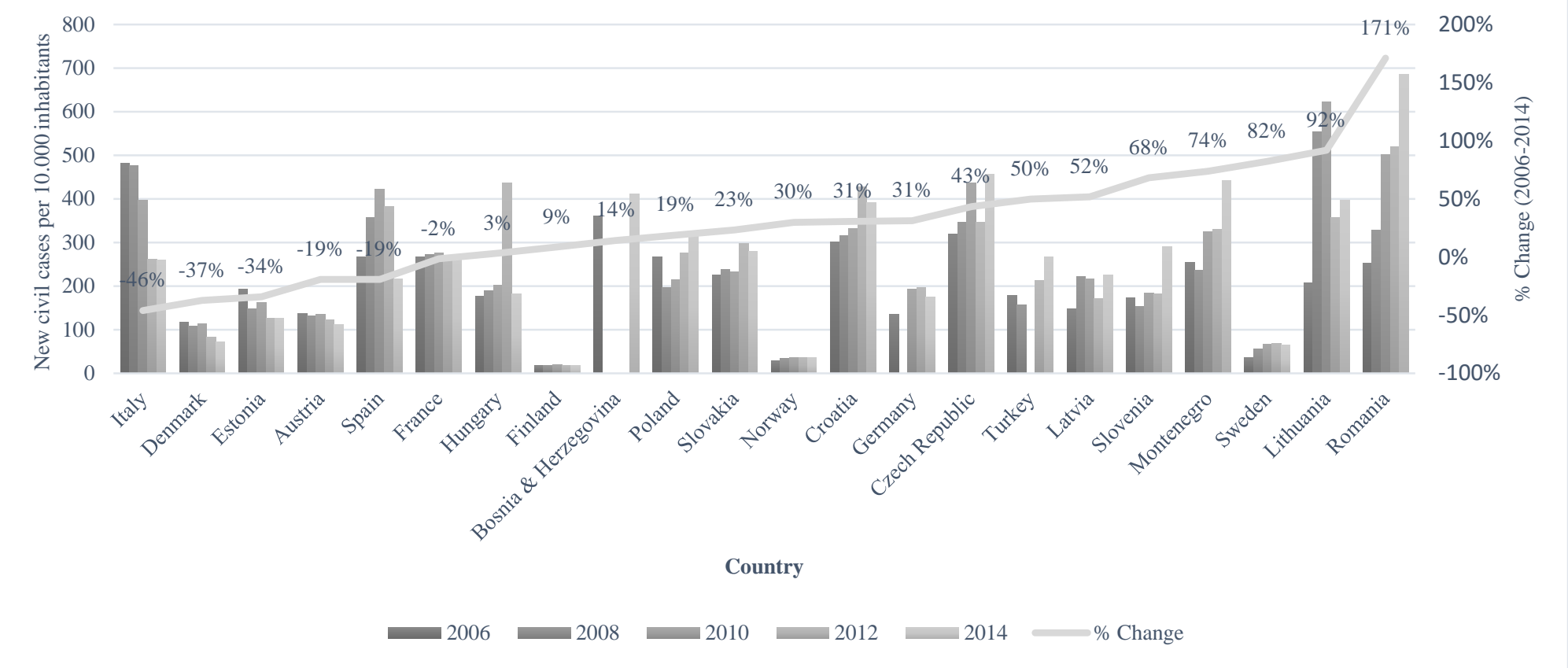


FIGURE 3: NUMBER OF LAWYERS PER 10,000 INHABITANTS IN 2014

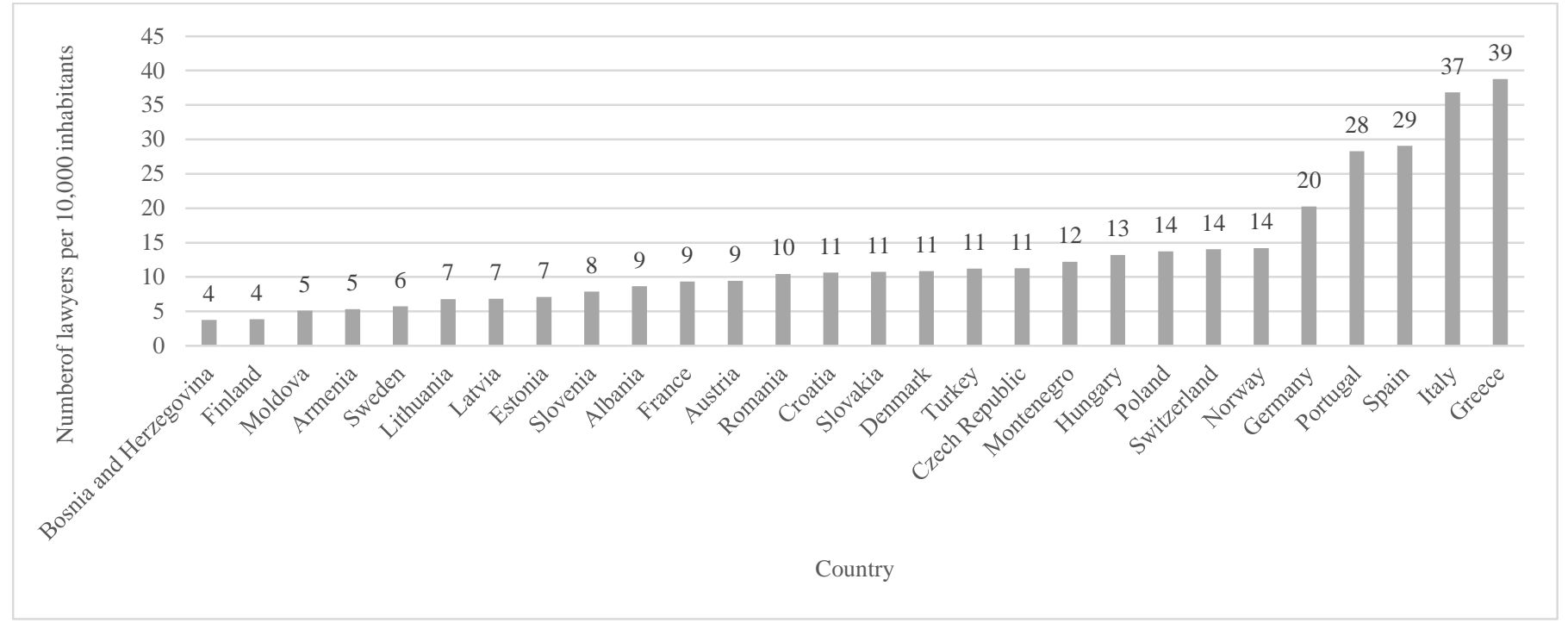


FIGURE 4: TIME EVOLUTION OF THE NUMBER OF LAWYERS PER 10,000 INHABITANTS BETWEEN 2006 AND 2014

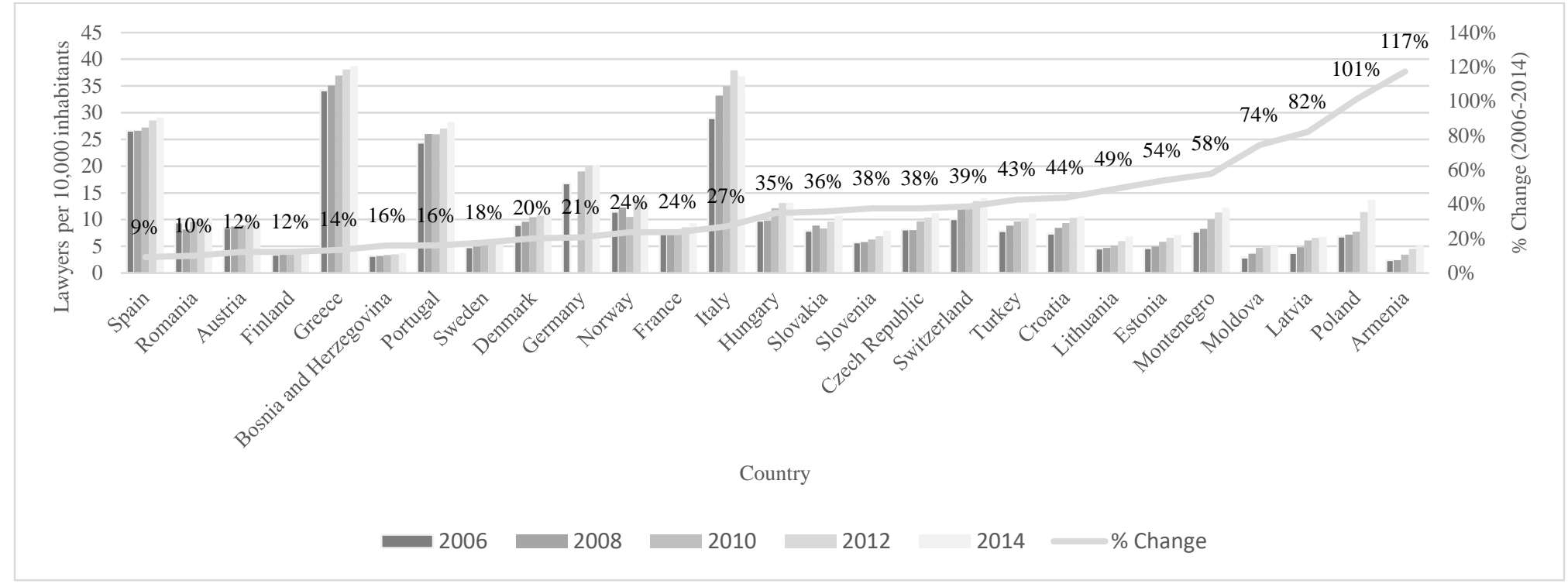

